GRADUATE JOURNAL.

\section{From biochemist to engineer}

When I was an undergraduate, I sculled my way into a new major - and onto a different career path. When I matriculated into McGill University, I started off in biochemistry and joined the rowing team. Two chemical-engineering student rowers introduced me to their programme during trips to competitions, and I decided to transfer to engineering.

After graduating, I worked as a junior process engineer for an engineering consultancy. A year later I returned to McGill for a master's degree, aiming to specialize in crystallization and learn project management. I was enthralled by the experience, but returned to industry.

A year later, I began to miss figuring out new phenomena, testing ideas in the lab and tutoring undergraduate students. I reflected on a paper I stumbled across during my master's that discussed the fabrication of ceramic bone biomaterials. I wondered if I could apply my knowledge to designing biomaterials for bone. With the reported mobility issues of the ageing population, I thought it would be motivating and inspiring to join a research team in this field. I was not sure if I could handle a second, longer, pay cut. I was more sure that I would regret it if I did not give it a try.

Sidney Omelon is a PhD student in bone biomaterials at the Samuel Lunenfeld Research Institute, Mount Sinai Hospital, Toronto, Canada.

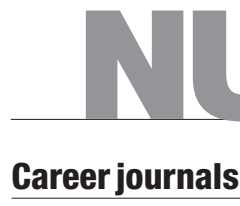

$R$ eflecting on your career tends to take a back seat to demanding schedules and work priorities. In the New Year there's no better way to remedy this than by keeping a career journal. This takes only a little time each month, yet the rewards are tenfold in career focus and effectiveness.

Whether you're a student, postdoc or midcareer scientist, making regular diary entries will give you an opportunity to reflect on your current state and future direction. And because your journal is intended for your eyes only, you don't have to worry about being judged on your career goals or your writing skills. If you've made your resolutions for the New Year, a journal will keep you on track. If you're lacking career direction, it will help you focus.

The discipline of regular writing will prompt you to

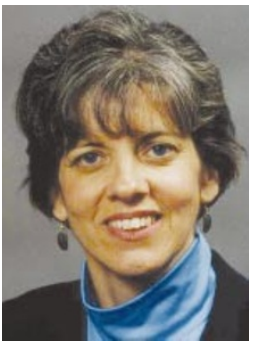

With Deb Koen Careers consultant

clarify your strengths and passions, identify gaps in expertise and tune in to personal development needs. By tracking progress over time, the journal will help you learn from mistakes and build on your strengths. The act of writing will solidify your thinking and serve as a catalyst for action.

Choose a notebook or create a PC file that will be immediately accessible when you want to capture a fleeting idea, need an outlet for your frustrations or have a reaction to a recent event. In addition to notes that you jot down spontaneously, schedule a 'journal hour' to recap each month.

Take a varied approach to writing. Start the hour with 15 minutes of uninterrupted and uncensored freestyle writing. Record whatever enters your mind about your career. Don't stop.

For a more structured recording, select a careerrelated theme and write away for 15-45 minutes. Topics might include peak moments at work, family influences on your career, work-life balance or lack of it, your sense of 'fit' in the organizational culture, potential career derailers, priority development needs, or trends most likely to have an impact on your career.

Now pull out a pen and notebook, or pull up a chair to your computer and start documenting the unfolding drama of your career.

Deb Koen is vice-president of Career Development Services and a columnist for The Wall Street JournaP's CareerJournal.com.

\section{E Ravinder Maini, board member, Domantis, Cambridge, UK}

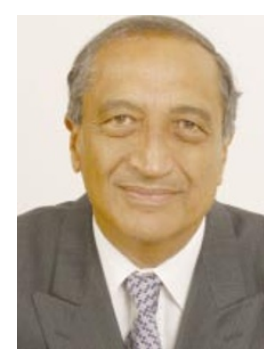

sardonically that insulin therapy "had put back research on diabetes" because it treated the symptoms - and thus had stifled research into the underlying mechanisms. That kind of critical thinking steered Maini towards research, rather than clinical practice. "I was inquisitive about biological mechanisms of disease," he says.

In 1968 he started work under Dudley Dumonde, one of the first in the United Kingdom to do cytokine research. His group eventually landed a grant to study cytokine expression in rheumatoid arthritis. "That's really where the course of my career changed dramatically," Maini says. But to develop his ideas he had to wait for technology to catch up.

It did when Greg Winter, co-founder of Domantis, humanized monoclonal antibodies and started using them to treat disease. And once the cytokine genes that interested Maini were cloned in the 1980s, he and his collaborator
Marc Feldmann realized that they could perhaps use monoclonal antibodies to treat rheumatoid arthritis and autoimmune diseases. These developments "opened the door", says Maini.

Now that the drugs he helped to develop have proved successful, Maini wants to make them more widely available. The cost of manufacturing therapeutic proteins means that a year's treatment can cost about $\$ 15,000$. So when Winter approached Maini to become involved with Domantis, he was eager, as the company's technology promises a cheaper and more specific way to make the proteins for treating the same autoimmune diseases.

Maini has never regretted pursuing clinical research - despite the 30-yearslog from concept to market. "Positive feedback keeps you going personally," Maini says - despite "considerable scepticism" at some points. 